\title{
Liver Involvement in Langerhans' Cell Histiocytosis A case report
}

\author{
N Musabbir ${ }^{1}$, A S M B Karim², K Sultana ${ }^{3}$, S A Anwar ${ }^{4}$
}

\section{Abstract}

Langerhans'cell histiocytosis (LCH) (Histiocytosis X) is a rare disease of unknown cause characterized by oligoclonal proliferation of Langerhans cells. It occurs mostly in children and young adults and involves one or more body systems such as bone, hypothalamus, posterior pituitary gland, lymph nodes, liver or various soft tissues. The diagnosis is always made by a histological approach.

A 3.5-year old male child with LCH involving multiple systems, including the skin, lungs, liver with clinical signs of diabetes insipidus. The patient was diagnosed following a skin biopsy that revealed infiltration of Langerhans cells. This case report would increase the awareness of pediatricians about the multisystem involvement in LCH.

Northern International Medical College Journal Vol. 7 No. 02 January 2016, Page 158-160

${ }^{1}$ Dr. Nadira Musabbir MD (Paediatric Gastroenterology) Banglabandhu Sheikh Mujib Medical University (BSMMU), Dhaka

Professor (Dr) ASM Bazlul Karim FCPS (Paediatrics)

Chairman, Dept. of Paediatric Gastroenterology and Nutrition BSMMU, Dhaka

${ }^{3}$ Dr. Kaniz Sultana MD (Paediatric Gastroenterology) BSMMU, Dhaka

${ }^{4}$ Dr. Syeda Afria Anwar MD (Paediatric Gastroenterology) BSMMU, Dhaka

Correspondence

Dr. Nadira Musabbir MD (Paediatric Gastroenterology) Banglabandhu Sheikh Mujib Medical University, Dhaka email : nadira_mou@yahoo.com

\section{Introduction}

Langerhans'cell histiocytosis (LCH) (Histiocytosis $\mathrm{X}$ ) is a clonal proliferative disorder of the Langerhans cells. ${ }^{1,{ }^{2}}$ The disease is rare, with an annual incidence of approximately 2-5 per million per year and a peak incidence at 1-4 years of age ${ }^{3}$. It may manifest at any age, with males being affected more frequently than females. The clinical presentation may be variable, either solitary disease of the bone, or severe multivisceral involvement (lung, bone, liver, spleen, lymph nodes, hypothalamus, pituitary gland, gastrointestinal tract, etc.). Liver involvement occurs mainly in multisystem involvement cases and usually presents as a part of a disseminated process. Among chil-dren with LCH (especially in children younger than 5 years old), liver involvement is relatively frequent, even though it is often overlooked. The diagnosis is based on cytology or histology in combination with immunohistochemical tests for S100 protein expression.

\section{Case report}

A 3.5-year-old child was admitted to the department of Pediatric Gastroenterology \& Nutrition of Bangabandhu Sheikh Mujib Medical University with history of not growing well, scaly skin lesion over scalp, chest, upper abdomen and back of the body with abdominal distension in association with polydipsia (2 I fluid per day), polyuria and 8 months history of jaundice. He has no history of fever, contact with TB patient, blood transfusion, any surgery or dental procedure, family history of liver disease, respiratory distress or bone pain. Physical examinations revealed skinny ill appearing patient with mild pallor and icterus. He has scaly skin lesion over chest, upper abdomen, scalp and back of body. He is a febrile, BCG mark present, stigmata of CLD absent. On anthropometric measurement, the child is severely wasted, stunted and underweight. Systemic examination revealed an enlarged liver. The laboratory data showed mild anemia $(\mathrm{Hb}$ : $9.6 \mathrm{~g} / \mathrm{dl})$, markedly raised ESR $\left(125 \mathrm{~mm}\right.$ in $1^{\text {st }}$ hour), evidence of cholestasis (S. bilirubin: 7.3 $\mathrm{mg} / \mathrm{dl}$, Direct bilirubin: $3.5 \mathrm{mg} / \mathrm{dl}$, S. ALT: 478 U/L, S. alkaline phosphatase : $2360 \mathrm{U} / \mathrm{L})$. Central Diabetic Insipidus is diagnosed as his serum osmolality was $305 \mathrm{mosm} / \mathrm{l}$ (> $300 \mathrm{mosm} / \mathrm{L}$ ) and urine osmolality was 89 mosm/ I (< 300 mosm/l) before giving DDAVP and after giving DDAVP urine osmolality became $187 \mathrm{mosm} / \mathrm{l}$ ( $>2$ fold of baseline). Abdominal ultrasonography revealed heterogenous echotexture of the liver with calcification. There was no lytic bone lesion of skull or spine on radiological examination. The chest X-ray film detected miliary opacities over both lung fields. MRI of brain showed no abnormality of hypothalamic- pituitary region. 
Bone marrow puncture showed no abnormality. Skin biopsy was done for confirmation of diagnosis of Langerhans'cell histiocytosis which showed collection of langerhans histiocytes in superficial dermis. The patient was referred to hematological department for specific management.

Treatment started with $1^{\text {st }}$ course of chemotherapy (vinblastine $6 \mathrm{mg} / \mathrm{m}^{2}$ intravenous bolus and prednisone $40 \mathrm{mg} / \mathrm{m}^{2} /$ day orally) and for diabetes insipidus, DDAVP nasal spray $(10 \mu \mathrm{g} /$ day) started after consultation with pediatric nephrology department. But after starting the treatment, patient party denied to continue the treatment and decided to take the child to abroad for further management. Regarding prognosis of this patient, as liver involvement is associated with high mortality rate, if treatment could be continued in this patient, chance of 3 year survival was only $51 \%$.

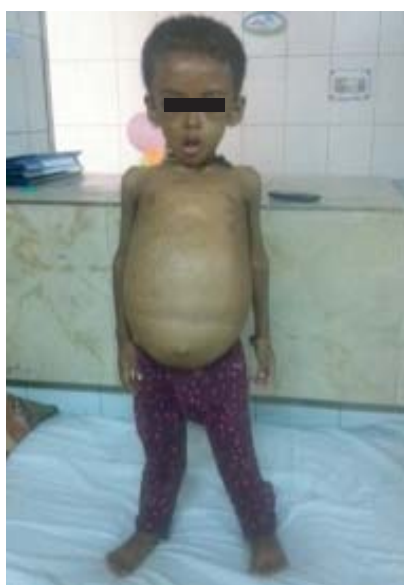

Fig 1 : patient

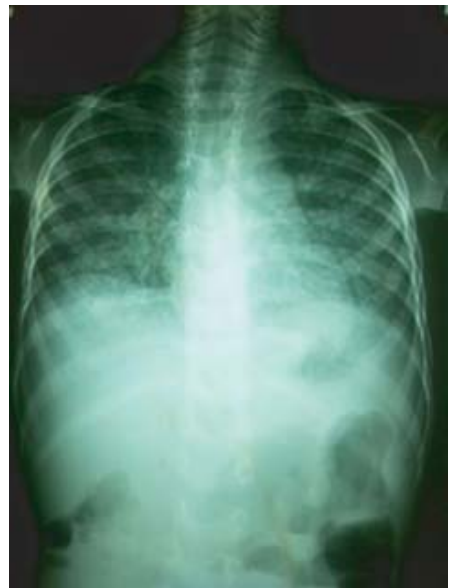

Fig 2 : Chest X-ray showing miliary opacity in both lung fields

\section{Discussion}

Langerhans'cell histiocytosis (LCH) is a rare proliferative disorder of the Langerhans cells. ${ }^{1}{ }^{2}$. The term encompasses the formerly known entities of histiocytosis $X$ that included Letterer Siwe disease, Hand Schuller Christian disease and eosinophilic granuloma. However, little is yet known about the etiology and pathogenesis of $\mathrm{LCH}$.

It occurs mostly in children and young adults, with males being affected more. Reported patient was also a male child of 3.5 years. The clinical presentation may be variable, and the course of the disease may show extreme case-to-case variation. The clinical course and outcome depend on the patient's age, the distribution and extension of the lesions, and the degree of organ dysfunction present at the time of initial diagnosis.

Although the rate of liver involvement is much lower than that in most other organs in LCH patients, it is relatively common in - disseminat-ed LCH representing $40 \%$ to $60 \%$ of the cases. In a review of 348 cases, the French Langerhans' Cell Histio-cytosis Study Group found liver involvement in $10.1 \%$ of patients during the initial episode, rising to $14.4 \%$ in subsequent episodes ${ }^{1}$. The latest monocentric pediatric study reported a $15.6 \%$ rate of liver involvement among 217 cases $^{11}$. Braier et al. report an $18 \%$ incidence of liver involvement in patients with multisystem $\mathrm{LCH}^{12}$. Therefore, liver involvement is probably more common than previously rec-ognized. It is vital to aware the pos-sibility of liver involvement once the diagnosis of $\mathrm{LCH}$ was established in children.

Liver involvement in children with LCH typically presents with hepatomegaly, abnormal liver enzymes, or jaundice, associated with multior-gan involvement. Reported patient also had jaundice, hepatomegaly with liver dysfunction. Diabetes insipidus together with the liver parenchymal infiltration and the cholestatic pattern of liver tests and pulmonary involvement found in reported patient raised the suspicion of a granulomatous disease such as histiocytosis $X$, but other diagnosis like disseminated TB was also considered which was excluded.

The definitive diagnosis is always based on histological examinations and confirmed by immunohistochemical tests. But unfortunately in this patient histological analysis of liver tissue was not done because patient party denied to do so. Skin biopsy was done which showed collection of langerhans histiocytes in superficial dermis.

However, because the pathophysiology of Langerhans cell histiocytosis is only poorly understood, treatment approaches remain empirical, and the response to treatment is sel-dom predictable ${ }^{13}$. When the liver is affected, treatment is aggressive due to the progressive irreversible damage due to cho-lestasis ${ }^{1}$.

The extent of the disease has a significant effect on the course of the disease and on its prognosis. Multivisceral forms are associated with a 4-year survival rate of $60-80 \%{ }^{11}$.

\section{Conclusion}

Liver involvement in $\mathrm{LCH}$ is not that much uncommon in children. So regular clinical and biochemical liver evaluation must be performed onwards to screen every LCH children from the time of the initial diagnosis and during the follow-up. Awareness of the varieties of ways that the disease can manifest itself and the wide spectrum of possible organ involvement is vital for pediatricians and radiologists who encounter this disease. 


\section{References}

1. Willman $\mathrm{CL}$, Busque $\mathrm{L}$, Griffith $\mathrm{BB}$ et al. Langerhans'cell histiocytosis (histiocytosis X) a clonal proliferative disease. N Engl J Med 1994; 331:154-160.

2. Emile JF, Fraitag $S$, Leborgne $M$ et al. Langerhans'cell histiocytosis cells are activated Langerhans'cells. J Pathol 1994; 174:71-76.

3. Salotti JA, Nanduri V, Pearce MS, Parker L, Lynn R, Windebank KP. Incidence and clinical features of Langerhans cell histiocytosis in the UK and Ireland. Arch Dis Child 2009; 94: 376-80.

4. Schmidt S, Eich G, Geoffray A, Hanquinet S, Waibel P, Wolf R, Letovanec I, Alamo-Maestre L, Gudinchet F. Extraosseous langerhans cell histiocytosis in children. Radiographics 2008; 28: 707-26.

5. Xiaoping Yi, Tong Han, Hongyan Zai, Xueying Long, Xiaoyi Wang, Wenzheng Li. Liver involvement of Langerhans' cell histiocytosis in children. Int J Clin Exp Med 2015; 8(5) : 7098-7106.

6. Jubran RF, Marachelian A, Dorey F, Malogolowkin M. Predictors of outcome in chil-dren with Langerhans cell histiocytosis. Pediatr Blood Cancer 2005; 45: 37-42.

7. Alston RD, Tatevossian RG, McNally RJ, Kelsey A, Birch JM, Eden TO. Incidence and survival of childhood Langerhans cell histiocytosis in Northwest England from 1954 to 1998. Pediatr Blood Cancer 2007; 48: 55560.

8. Campos MK, Viana MB, De Oliveira BM, Ribeiro DD, Silva CM. Langerhans cell histiocytosis: a 16-year experience. J Pediatr (Rio J) 2007; 83: 79-86.

9. Arico M, Girschikofsky M, Généreau T, Klersy C, McClain K, Grois N, Emile JF, Lukina E, De Juli E, Danesino C. Langerhans cell histiocytosis in adults. Report from the International Registry of the Histiocyte Society. Eur ] Cancer 2003; 39: 2341-8.

10. A multicentre retrospective survey of Langerhans' cell histiocytosis: 348 cases ob-served between 1983 and 1993. The French Langerhans' Cell Histiocytosis Study Group. Arch Dis Child 1996; 75: 17-24.

11. Campos MK, Viana MB, De Oliveira BM, Ribeiro DD, Silva CM. Langerhans cell histiocytosis: retrospective analysis of 217 cases in a single center. Pediatr Hematol Oncol 2008; 25: 399-408.

12. Braier J, Ciocca M, Latella A, De Davila MG, Drajer M, Imventarza 0 . Cholestasis, scleros-ing cholangitis, and liver transplantation in Langerhans cell Histiocytosis. Med Pediatr Oncol 2002; 38: 178-82.

13. Savasan S. An enigmatic disease: childhood Langerhans cell histiocytosis in 2005. Int J Dermatol 2006; 45: 182-8.

14. Jaffe R. Liver involvement in the histiocytic dis-orders of childhood. Pediatr Dev Pathol 2004; 7: 214-25.

15. Gadner H, Heitger A, Grois N et al. Treatment strategy for disseminated Langerhans'cell histiocytosis. Med Pediatr Oncol 1994; 23:72-80. 